\title{
CHEMICAL COMPOSITION OF PRECIPITATION AT COASTAL AND MARINE SAMPLING SITES IN MEXICO
}

\author{
R.M. CERÓN ${ }^{1}$ \\ J.G. CERÓN ${ }^{*}$ \\ A.V. CÓRDOVA ${ }^{1}$ \\ J. ZAVALA ${ }^{1}$ \\ M. MURIEL ${ }^{2}$
}

\author{
${ }^{1}$ Facultad de Química \\ Universidad Autónoma del Carmen \\ Calle 56 No. 4 x Avenida Concordia \\ 24180. Ciudad del Carmen, Campeche. México \\ ${ }^{2}$ Instituto Mexicano del Petróleo \\ Competencia de Medioambiente y Seguridad \\ Dirección Regional Zona Marina \\ Av. Periférica Norte S/N Esquina Calle 35B \\ Col. San Agustín del Palmar \\ 24118. Ciudad del Carmen, Campeche. México
}

*to whom all correspondence should be addressed

Tel.-Fax: +52019383826514

Received: 19/01/05

Accepted: 30/07/05

\begin{abstract}
Chemical characteristics of wet precipitation were measured in Acapulco, Cancun, Tapachula, Puerto Morelos and Tropical Pacific Ocean; from August 1999 to October 2001. The samples were analyzed for $\mathrm{pH}, \mathrm{Na}^{+}, \mathrm{K}^{+}, \mathrm{Ca}^{2+}, \mathrm{Mg}^{2+}, \mathrm{NH}_{4}{ }^{+}, \mathrm{SO}_{4}{ }^{2-}, \mathrm{NO}_{3}{ }^{-}$and $\mathrm{Cl}^{-}$. Ionic abundance revealed a significant variation, however, the most abundant ions were sodium, chloride and magnesium in all sites. $\mathrm{pH}$ values observed were within the normal $\mathrm{pH}$ value considered for rainwater, and agree with that reported by other authors in marine and coastal sites; sea-salt aerosol contributed with most of $\mathrm{Na}^{+}, \mathrm{Cl}^{-}$and $\mathrm{Mg}^{2+}$, whereas, a significant proportion of $\mathrm{K}^{+}$and $\mathrm{Ca}^{2+}$ originated in particles from soil; finally sulfate excess concentration was in agreement with the background hemispheric values.

In the other hand, in Puerto Morelos, during sampling campaign performed at the end of the mid-summer drought, $\mathrm{NO}_{3}^{-}$levels were the highest and also higher than $\mathrm{SO}_{4}{ }^{2-}$ concentrations, exceeding background level; and $\mathrm{pH}$ values observed were low. Excluding, Puerto Morelos, where other sources influenced the rain chemistry composition; all remaining sampling sites were clearly influenced by marine aerosol, showing ionic concentrations typical of sites with a minimal anthropogenic influence, and therefore, their ionic concentrations can be considered as representative of background values for this region.
\end{abstract}

KEY WORDS: Tropical oceanic rain; coastal rainwater chemistry; Mexico.

\section{INTRODUCTION}

Temporal and spatial trends in precipitation chemistry are affected by seasonal variations in biogenic emissions, local agricultural practices, long-range transport, local meteorology, marine salt, and episodes like hurricanes and volcanic activity. In coastal sites, sea-salt aerosol dominates precipitation chemistry, accounting for $95-100 \% \mathrm{of} \mathrm{Na}^{+}$, $\mathrm{Cl}^{-}$and $\mathrm{Mg}^{2+}$. On the other hand, $\mathrm{K}^{+}$and $\mathrm{Ca}^{2+}$ show an excess that exhibit a geographical variation and whose origin is in most of cases limestone particles. 
Additionally, $\mathrm{SO}_{4}{ }^{2-}$ concentration frequently presents an excess, whose origin is different of sea salt. Numerous studies report a good correlation between sulfate excess in precipitation and atmospheric $\mathrm{SO}_{2}$, and concluded that both species have a marine origin. It has been demonstrated that $\mathrm{SO}_{2}$ levels in a marine atmosphere increase with primary productivity in surface waters (probably due to production of dimethyl sulfide), suggesting that biological processes can be important to explain sulfate excess in rainwater in marine and coastal zones. Even in remote sites, it has been found that the presence of a sulfate fraction does not depend on sea salt. Reported levels are mostly low and agree with background level proposed by Galloway et al (1983) as representative from remote marine sites. Background concentrations are usually measured at remote sites from anthropogenic sources, and are useful to establish a reference point for comparison with urban and industrial areas (Vong, 1990). So, when $\left(\mathrm{SO}_{4}{ }^{2-}\right)_{\mathrm{xs}}$ levels exceed this background value, there are three possible sources: local production of acids, natural emission from biogenic activity in surface ocean, and long-range transport.

The lack of $\mathrm{NO}_{3}{ }^{-}$and $\mathrm{NH}_{4}{ }^{+}$in rainwater marine fraction in remote coastal sites, confirms its anthropogenic origin. $\mathrm{NH}_{4}{ }^{+}$and $\mathrm{NO}_{3}{ }^{-}$concentrations are very low, however, when the site becomes less remote, depending on influence of anthropogenic sources or biomass fires, their concentrations tend to exceed the background value proposed by Casimiro et al. (1991) for remote marine sites.

Some authors have depicted different patterns associated with dry and humid periods, and has been observed that dilution contributes at least in part to this patterns (Eklund et al, 1997). However, influence of local anthropogenic sources, long-range transport, and the occurrence of extraordinary events like hurricanes, volcanic fumaroles and forest fires, can modify such patterns. In this case, besides year season and the correlation between rainwater constituents, the analysis of air-mass trajectories and of surface winds during individual precipitation events with a high $\mathrm{NO}_{3}{ }^{-}$or $\left(\mathrm{SO}_{4}{ }^{2-}\right)_{\mathrm{xs}}$ content is a useful tool to identify possible sources.

In the Caribbean Sea, there is a clear increase in $\mathrm{H}_{2} \mathrm{SO}_{4}$ and $\mathrm{HNO}_{3}$ contribution to rainwater acidity when air masses move toward Gulf of Mexico; furthermore, in Yucatan Peninsula, some previous non systematic studies of rainwater acidity and their effects on Mayan monuments revealed $\left(\mathrm{SO}_{4}{ }^{2-}\right)_{\mathrm{xs}}$ levels, comparable to background value proposed by Galloway et al. (1983) for remote marine sites (Bravo et al., 2000); however, $\mathrm{NO}_{3}{ }^{-}$ levels found, were four times higher than background concentration proposed by Casimiro et al .(1991).

There are several works about precipitation chemical composition in urban, semi-urban and industrial areas in Mexico (Báez and Belmont, 1987; Báez et al., 1993; Báez et al., 1997a; Báez et al., 1997b). In contrast, reports regarding coastal and marine sites with a minimal anthropogenic influence are scarce or non-existent; consequently, background characteristics and the impact from marine aerosol and anthropogenic emissions on chemical composition of rainwater in these zones, are unknown yet. Therefore, the purpose of the present research was to study chemical composition of rainwater in marine and coastal sites in the southeast of Mexico in order to identify the influence of sea salt aerosol on precipitation chemistry and the possible sources of ions in precipitation.

\section{METHODS}

\section{Site description}

Five campaigns were performed during present research work. Samples were collected in Acapulco, Cancun, Puerto Morelos, Tapachula and Tropical Pacific Ocean (Figure 1). 


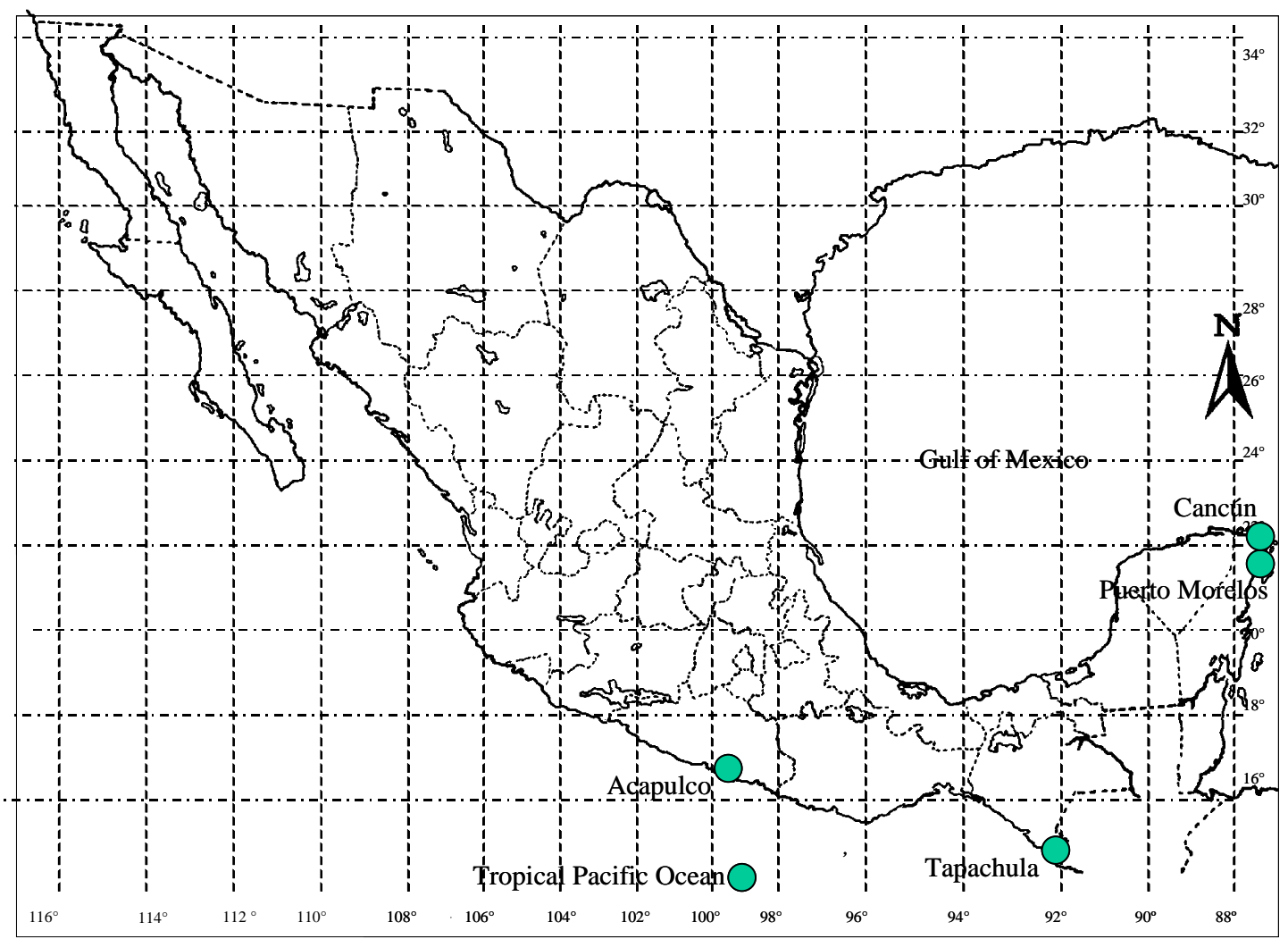

Figure 1. Sampling sites location: Acapulco., Cancún., Puerto Morelos., Tapachula and Tropical Pacific Ocean

Acapulco is a coastal site located in south region of Guerrero state at $16^{\circ} 41^{\prime} \mathrm{N}, 99^{\circ} 32^{\prime}$ W. Cancun ( $21^{\circ} 11 \mathrm{~N}, 86^{\circ} 43^{\prime} \mathrm{W}$ ) is placed on the Caribbean coast of the Yucatan Peninsula with a maximal altitude of 10 meters above sea level. Puerto Morelos is situated in northeastern coast of Yucatan Peninsula at 20 $50^{\prime} \mathrm{N}, 86^{\circ} 54^{\prime}$ W along Mayan Riviera. Because of its latitude, Cancun and Puerto Morelos are exposed to marine winds from the Caribbean Sea most of the year. Tapachula $\left(14^{\circ} 54^{\prime} \mathrm{N}, 92^{\circ} 16^{\prime} \mathrm{W}\right.$ ) is a coastal city located in the south of Chiapas state. All sites were flat, without volcanic activity, and located at maximal distance of $20 \mathrm{~km}$ from coast. Some samples were collected on board of oceanographic ship "PUMA"; this sampling station in Tropical Pacific Ocean was limited by geographical coordinates $12-14^{\circ} \mathrm{N}$ and $98-100^{\circ} \mathrm{W}$. All sampling sites were located upwind from local or regional pollution sources.

\section{Sampling method}

Sampling protocol followed all recommendations proposed by Galloway and Likens (1978). Only wet precipitation was collected, in all sampling sites during summer season, from 24 August 1999 to 4 October 2001. In the case of Acapulco, Cancun and Tapachula, collectors were located on the roof of hotels; while, in Puerto Morelos, the rain collector was placed at the top of a meteorological station on a near wharf. On the other hand, on board of oceanographic ship "PUMA", collector was placed similar to Galloway et al (1983) work. In all cases, the rain sampler consisted of a $27 \mathrm{~cm}$ diameter funnel connected to a 2 I HDPE bottle, and a standard rain gauge was used to determine rain quantity. Individual rain events were collected, and when it was possible, a sequential sampling was performed. The funnel was manually covered between rain events, uncovered and rinsed with deionized water just before each precipitation event started. Rainwater samples were stored at $4^{\circ} \mathrm{C}$ immediately after collection and sent to Atmospheric Chemistry Laboratory of National University of Mexico, in Mexico City at the end of the sampling period. 


\section{Meteorological data}

Meteorological data were obtained from field station operated by the Sea Sciences Institute Experimental Station of the National University of Mexico. Wind parameters were obtained and handled for each individual rain event to identify possible polluting sources. Moreover, air-parcel back trajectories (at surface level and at three different heights) for whole sampling period were performed (Cerón, 2002) by HYSPLIT model.

\section{Analytical procedure}

Sodium, $\mathrm{K}^{+}, \mathrm{Ca}^{2+}$ and $\mathrm{Mg}^{2+}$, were analyzed by flame atomic absorption spectrometry, using a GBC 932AA double beam atomic absorption spectrophotometer. Chloride, nitrate and sulfate were analyzed by non-suppressed chromatography, and ammonium by suppressed chromatography with a Perkin-Elmer chromatograph. Injection volume was $100 \mu \mathrm{l}$ for anions, while for ammonium was $50 \mu \mathrm{l}$. Minimum detectable concentrations in $\mathrm{mg} \mathrm{l}^{-1}$ were: $0.22,0.04,0.17,0.002,0.006,0.01,0.002$, and 0.042 for $\mathrm{SO}_{4}{ }^{2-}, \mathrm{Cl}^{-}, \mathrm{NO}_{3}^{-}$, $\mathrm{Na}^{+}, \mathrm{K}^{+}, \mathrm{Ca}^{2+}, \mathrm{Mg}^{2+}$, and $\mathrm{NH}_{4}^{+}$, respectively. Measurements of sample $\mathrm{pH}$ were made using an Orion 960 autochemistry system with a combination glass electrode. Calibration was performed using buffer solutions at $\mathrm{pH} 4$ and 7 . Conductivity measurements were performed using an YSI 3200 conductivity meter.

Ion balance and conductance percent data differences were used for quality assurance following the criteria established by Peden et al (1986). Also, field blanks were analyzed to guarantee the cleanness of the sampling material; and replicates were run routinely to assure appropriate precision and accuracy.

\section{RESULTS AND DISCUSSION Ionic characteristics}

Table 1 shows the volume-weighted mean concentrations (VWM) of all collected samples in Acapulco, Gro; Cancun, QRoo; Tapachula, Chis; Puerto Morelos, QRoo; and Tropical Pacific Ocean. The ionic abundance in rainwater showed the following general trend for anions: $\mathrm{Cl}^{-}>\mathrm{SO}_{4}{ }^{2-}>\mathrm{NO}_{3}{ }^{-}$, except for Puerto Morelos, where nitrate levels were higher than sulfate one. In the case of cations, the ionic abundance showed a significant variation, however, in all sites, the most abundant cations were sodium and magnesium.

Measured concentrations in wetfall samples for all sites considered in this research were compared with representative data from other marine and coastal sites of the region (Table 2). Except for $\mathrm{Ca}^{2+}$ and $\mathrm{NO}_{3}{ }^{-}$, ionic concentrations of all constituents were in agreement with that reported by several authors in marine and coastal sites (Bravo et al., 2000; Clark et al., 1998; Eklund et al., 1997; McDowell et al., 1990; Galloway et al., 1989; Hendry et al., 1984; Galloway et al., 1983; Galloway et al., 1982).

Since some ions did not have a lognormal distribution, in order to determine if there were significant differences among ionic concentrations in rainwater collected in all sites considered, the Kruskal-Wallis test was applied to data (Table 3). All ions showed significant differences at a significance level of $95 \%(p \leq 0.05)$, so it was necessary to apply the Mann-Whitney Test for paired samples. Sodium and $\mathrm{Cl}^{-}$levels were higher in sites exposed mainly to maritime air, like Cancun, Puerto Morelos and Tropical Pacific Ocean. $\mathrm{Ca}^{2+}$ and $\mathrm{K}^{+}$concentrations were very low, significant differences were observed among sampled sites, and relative high concentrations were found in Cancun and Tapachula, where the uptake of soil particles was probably abundant. The low calcium levels found in Acapulco and Tropical Pacific Ocean can have two explanations: First, that $\mathrm{Ca}^{2+}$ levels present in marine aerosol or soil particles were low, and second, because of high precipitation rates, the high moisture soil avoid the uptake of limestone particles to rainwater. 
Table 1.Volume-weighted mean concentrations (VWM) in $\mu \mathrm{Eq} \mathrm{I}^{-1}$ for wet precipitation collected in all sampling sites considered by this research

\begin{tabular}{|l|c|c|c|c|c|c|c|c|c|}
\hline \multicolumn{1}{|c|}{ Sampling site } & $\mathbf{S O}_{4}{ }^{2-}$ & $\mathbf{C l}$ & $\mathbf{N O}_{3}^{-}$ & $\mathbf{N a}^{+}$ & $\mathbf{K}^{+}$ & $\mathbf{C a}^{2+}$ & $\mathbf{M g}^{2+}$ & $\mathbf{N H}_{4}^{+}$ & $\mathbf{H}^{+}$ \\
\hline Acapulco. N = 16. & 7.2 & 34.3 & 3.2 & 26.1 & 0.9 & 3.9 & 6.6 & 3.0 & 1.1 \\
\hline August 24-26 (1999) & & & & & & & & & \\
\hline Cancún. N = 10. & 11.8 & 62.3 & 1.9 & 57.7 & 2.7 & 26.8 & 11.6 & 3.7 & 0.7 \\
\hline October 1-2 (1999) & & & & & & & & & \\
\hline Tapachula. N = 15. & 12.9 & 17.5 & 6.7 & 8.5 & 1.6 & 5.0 & 2.1 & 14.5 & 5.2 \\
\hline August 25-September 25 (1999) & & & & & & & & & \\
\hline Puerto Morelos. N = 11. & 28.1 & 140.9 & 67.9 & 118.6 & 3.1 & 12.9 & 26.0 & 6.8 & 69.8 \\
\hline August 27-September 7 (2000) & & & & & & & & & \\
\hline Tropical Ocean Pacific. N = 21. & 18.4 & 86.9 & 3.9 & 102.9 & 2.7 & 4.2 & 24.1 & 8.5 & 1.7 \\
\hline May 23-September 6 (2001) & & & & & & & & & \\
\hline Puerto Morelos. N = 43. & 20.4 & 126.9 & 4.2 & 116.2 & 1.5 & 2.3 & 25.9 & 2.3 & 3.1 \\
\hline September 13-October 4 (2001) & & & & & & & & & \\
\hline
\end{tabular}

$\mathrm{N}=$ Number of samples.

* Sampling performed during occurrence of forest fires (at the end of the mid-summer drought).

Table 2.Volume-weighted mean concentrations (VWM) in $\mu \mathrm{Eq} \mathrm{I} \mathrm{I}^{-1}$ for wet precipitation collected in other coastal and marine reference sites

\begin{tabular}{|l|c|c|c|c|c|c|c|c|c|}
\hline \multicolumn{1}{|c|}{ Sampling site } & $\mathbf{S O}_{4}{ }^{2-}$ & $\mathbf{C l}$ & $\mathbf{N O}_{3}{ }^{-}$ & $\mathbf{~ N a}^{+}$ & $\mathbf{K}^{+}$ & $\mathbf{C a}^{2+}$ & $\mathbf{M g}^{2+}$ & $\mathbf{~ N H}_{4}{ }^{+}$ & $\mathbf{H}^{+}$ \\
\hline La Selva, Costa Rica. & 17.7 & 47.6 & 5.3 & 38.9 & 2.3 & 7.1 & 10.1 & 8.7 & 5.4 \\
\hline Eklund et al (1997). & & & & & & & & & \\
\hline El Verde, Puerto Rico. & 17.0 & 82.0 & 4.3 & 66.0 & 1.8 & 8.5 & 15.0 & 2.9 & 7.5 \\
\hline McDowell et al (1990) & & & & & & & & & \\
\hline Turrialba, Costa Rica. & 9.0 & 15.0 & 1.4 & 11.3 & 3.8 & 3.0 & 4.0 & 4.2 & 3.5 \\
\hline Hendry et al (1984). & 27.2 & 185.3 & 1.7 & 165.0 & 3.4 & 10.8 & 38.8 & 6.8 & 13.1 \\
\hline SS Doric Ship NY-Bermuda. & & & & & & & & & \\
\hline Galloway et al (1983). & 28.7 & 142.6 & 7.1 & 116.5 & 16.2 & 9.5 & 21.8 & 3.7 & 21.5 \\
\hline $\begin{array}{l}\text { SS Oceanic Ship NY-Bermuda- } \\
\text { Nassau. }\end{array}$ & & & & & & & & & \\
\hline Galloway et al (1983). & 25.4 & 150.7 & 11.4 & 128.7 & 5.8 & 17.8 & 28.6 & 6.4 & 4.5 \\
\hline Yucatán Peninsula. & & & & & & & & & \\
\hline Bravo et al (2000). & 36.3 & 175.0 & 5.5 & 147.0 & 4.3 & 9.7 & 34.5 & 3.8 & 16.2 \\
\hline Bermuda. & & & & & & & & & \\
\hline Galloway et al (1982). & & & & & & &
\end{tabular}

Sulfate excess levels agreed with background hemispheric values $\left(10 \mu \mathrm{Eq} \mathrm{I}^{-1}\right)$ reported by Galloway et al. (1983) and Casimiro et al. (1991). Significant differences in $\mathrm{NH}_{4}^{+}$levels among sampled sites were observed (Table 3), the highest concentrations was found in Tapachula; it suggests an evident but not significant influence from continent because of land agricultural use in this site. Nitrate concentrations were very low, with exception of Puerto Morelos, where $\mathrm{NO}_{3}{ }^{-}$levels were significantly high, exceeding the atmospheric background value $\left(2.8 \mu \mathrm{Eq} \mathrm{I}^{-1}\right)$ proposed for marine and coastal sites. The main source identified for these high $\mathrm{NO}_{3}{ }^{-}$levels was forest fires influence that occurred during midsummer drought (Cerón et al., 2002).

An interelemental regression analysis was performed to obtain correlation matrices at a significance level of $95 \%$. The high correlation coefficients between $\mathrm{Na}^{+}-\mathrm{Cl}^{-}, \mathrm{Na}^{+}-\mathrm{Mg}^{2+}$, $\mathrm{Na}^{+}-\mathrm{K}^{+}, \mathrm{K}^{+}-\mathrm{Cl}^{-}, \mathrm{Mg}^{2+}-\mathrm{Cl}^{-}, \mathrm{Mg}^{2+}-\mathrm{K}^{+}, \mathrm{Ca}^{2+}-\mathrm{K}^{+}$, and $\mathrm{SO}_{4}{ }^{2-}-\mathrm{Cl}^{-}$; suggests a common source between these constituents; whereas the good correlation between $\mathrm{Na}^{+}-\mathrm{SO}_{4}{ }^{2-}, \mathrm{K}^{+}-\mathrm{SO}_{4}{ }^{2-}$, $\mathrm{Ca}^{2+}-\mathrm{SO}_{4}{ }^{2-}, \mathrm{Mg}^{2+}-\mathrm{SO}_{4}{ }^{2-}, \mathrm{NH}_{4}{ }^{+}-\mathrm{SO}_{4}{ }^{2-}, \mathrm{Na}^{+}-\mathrm{NO}_{3}{ }^{-}, \mathrm{K}^{+}-\mathrm{NO}_{3}{ }^{-}, \mathrm{Mg}^{2+}-\mathrm{NO}_{3}{ }^{-}$, and $\mathrm{NH}_{4}{ }^{+}-\mathrm{NO}_{3}{ }^{-}$, is result of neutralization processes of strong acids with alkaline species in precipitation. Only rainwater collected in Puerto Morelos showed a significant inverse correlation 
between $\mathrm{H}^{+}-\mathrm{NO}_{3}{ }^{-}$and $\mathrm{pH}-\mathrm{NO}_{3}{ }^{-}$, suggesting a strong contribution from nitrate to rainwater acidity in this site.

Table 3. Comparison among sampling sites in this research (Acapulco, Tapachula, Cancun, Puerto Morelos and Tropical Pacific Ocean) using the Kruskal-Wallis Test

\begin{tabular}{cc}
\hline Ion & $\chi^{2}$ Statistic \\
\hline $\mathrm{SO}_{4}{ }^{2-}$ & $33.496^{\star}$ \\
\hline $\mathrm{Cl}^{-}$ & $53.422^{\star}$ \\
\hline $\mathrm{NO}_{3}{ }^{-}$ & $80.148^{\star}$ \\
\hline $\mathrm{NH}_{4}^{-}$ & $51.432^{*}$ \\
\hline $\mathrm{Na}^{+}$ & $55.071^{\star}$ \\
\hline $\mathrm{K}^{+}$ & $20.142^{\star}$ \\
\hline $\mathrm{Mg}^{2+}$ & $48.457^{*}$ \\
\hline $\mathrm{Ca}^{2+}$ & $53.195^{\star}$ \\
\hline
\end{tabular}

Sampling sizes were: 16 in Acapulco (1999); 10 in Cancún (1999);

15 in Tapachula (1999); 28 in Puerto Morelos (2000); 21 in

Tropical Pacific Ocean (2002) and 43 in Puerto Morelos (2001).

* Significance level of $95 \%$.

\section{Sequential sampling}

Chemical composition of sequentially collected samples was determined in all sampling sites. At the beginning of the rain event, pollutant concentration in the air is relative high, and a rapid decrease in ionic concentration in the early portion of the rainfall is observed; as the rain event progresses, drops evaporating and available pollutants decrease; whereas ionic concentrations increase or stay without change during the latter part of the event. Scavenging processes controlling wet precipitation, are determined by the properties of the particulated matter, gas solubility and type of precipitation (Lim et al, 1991). Influence of these scavenging processes is evident in changes of concentration of the ionic components in rainwater. This decrease in constituents concentration during rain events has also been observed by other authors (Seymour and Stout, 1983; Ahmed et al., 1990; Lim et al., 1991; Báez et al., 1993), and it has been attributed to several possible effects: within cloud scavenging, dilution with cloud droplet growth, below cloud scavenging, evaporation and evaporation followed by accumulation of aerosol particle aloft and precipitation of these accumulated particles.

\section{Precipitation acidity}

Values of $\mathrm{pH}$ observed in rainwater of all sampling sites are given in Table 4. With exception of Puerto Morelos, $\mathrm{pH}$ values observed were within the $\mathrm{pH}$ considered normal for rainwater, and agree with that reported by other authors in marine and coastal sites (Bravo et al., 2000; Clark et al., 1998; Eklund et al., 1997; McDowell et al., 1990; Galloway et al., 1989; Hendry et al., 1984; Galloway et al., 1983; Galloway et al., 1982). More than $80 \%$ of rainwater samples in Puerto Morelos had $\mathrm{pH}$ values below the limit of natural rain $(\mathrm{pH}<5.6)$, this acidity was attributed to forest fires that occurred during midsummer drought. The importance of Washout process is evident in all sequential studies of rainwater chemical composition: due to rainout processes of acidic material within the clouds, the $\mathrm{pH}$ of precipitation is initially acidic, subsequently, during the passage of raindrops from the cloud base downwards, washout processes of alkaline substances in the atmosphere, result in the rapid neutralization of precipitation acidity. As rainfall progresses in time, washout of alkaline particles is completed and then, precipitation acidity picks up again as a result of input due to rainout processes.

The contribution of $\mathrm{NO}_{3}{ }^{-}$and $\mathrm{SO}_{4}{ }^{2-}$ to rainwater acidity was obtained from average ionic equivalent ratios $\mathrm{NO}_{3}^{-} / \mathrm{H}^{+}$and $\mathrm{SO}_{4}{ }^{2-} / \mathrm{H}^{+}$. In all sampled sites $\mathrm{SO}_{4}{ }^{2-}$ contributed in a major proportion to the acidity in comparison with $\mathrm{NO}_{3}{ }^{-}$, with exception of Puerto Morelos, where $\mathrm{NO}_{3}{ }^{-}$was the main donator of protons. 
Table 4. Average $\mathrm{pH}$ values for all sites sampled in this study

\begin{tabular}{lccc}
\hline \multicolumn{1}{c}{ Sampling Site. } & Mean & Minimum & Maximum \\
\hline Acapulco & 5.96 & 5.75 & 6.24 \\
\hline Cancún & 6.14 & 5.95 & 6.84 \\
\hline Tapachula & 5.28 & 4.67 & 6.27 \\
\hline Puerto Morelos & & 3.48 & 5.96 \\
\hline Tropical Pacific Ocean $^{*}$ & 5.56 & 5.45 & 6.22 \\
\hline Puerto Morelos & 5.59 & 5.06 & 6.02 \\
\hline
\end{tabular}

* During mid-summer drought (2000).

${ }^{*}$ In the plenitude of the wet season (2001).

\section{Meteorological influence}

Several authors have assessed the influence of environmental factors like precipitation intensity, velocity and wind direction upon chemical composition of rainwater (Singh et al., 1987; Raynor and Hayes, 1982; Savoie et al., 1987); and is a common practice to use meteorological data to explain this variability.

Precipitation quantity was significantly inverse correlated with $\mathrm{Na}^{+}, \mathrm{K}^{+}, \mathrm{Ca}^{2+}, \mathrm{Mg}^{2+}, \mathrm{NH}_{4}^{+}$, $\mathrm{SO}_{4}{ }^{2-}$ and $\mathrm{Cl}^{-}$; therefore, the highest ionic concentrations were observed with slight rains, and there was a trend to lower concentrations as the precipitation intensity increased. This effect of dilution has also been reported by other authors (Savoie et al., 1987; Saylor et al., 1992; Báez et al., 1997a; Eklund et al., 1997), however, except for Puerto Morelos, in the remaining sampled sites, nitrate ion did not show a significant inverse correlation with rain quantity, probably due to low concentrations measured.

Because of sampling campaigns were performed only during summer months, seasonal patterns could not been assessed. Air mass back trajectories obtained for the whole sampling period from HYSPLIT model showed that all sites were under maritime air influence as was expected. However, from an analysis of surface wind data during individual events of precipitation, forest fires were identified as the main source of the high nitrate levels observed in Puerto Morelos at the end of the mid-summer drought (Cerón et al., 2002).

\section{Sources of dissolved ions in precipitation.}

In order to explore possible geochemical and anthropogenic sources for dissolved compounds in rainwater, $\mathrm{Cl}^{-}$was used as a tracer element for marine aerosol (Duce and Hoffman, 1976); therefore, it was carried out the following analysis:

1. Enrichment factors (EF) for each ion relative to sea salt were calculated as follows:

$\mathrm{EF}_{\mathrm{Cl}}(\mathrm{X})=\left(\mathrm{X} / \mathrm{Cl}^{-}\right)_{\text {rain }} /\left(\mathrm{X} / \mathrm{Cl}^{-}\right)_{\text {sea water }}$

where $\left(\mathrm{X} / \mathrm{Cl}^{-}\right)_{\text {rain }}$ is the ratio between substance $X$ concentration and $\mathrm{Cl}^{-}$concentration in rainwater; and $\left(\mathrm{X} / \mathrm{Cl}^{-}\right)_{\text {sea water }}$ is the ratio of substance $X$ relative to $\mathrm{Cl}^{-}$in sea water, reported elsewhere (Culkin and Cox, 1966; Morris and Riley, 1966).

2. The ions excess relative to chloride for the constituents of rainwater was determined as follow:

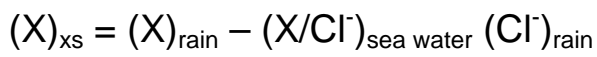

where $(X)_{x s}$ is the concentration in excess of $X$ substance, and, $\mathrm{Cl}^{-}$rain and $\mathrm{X}_{\text {rain }}$ are the dissolved concentration of substance $\mathrm{X}$ and $\mathrm{Cl}^{-}$ion in rainwater.

3. Sea salt fractions of ions (SSF) were determined as follow:

$\mathrm{SSF}=\mathrm{Cl}_{\text {rain }}^{-}\left(\mathrm{X} / \mathrm{Cl}^{-}\right)_{\text {sea water }}(100) / \mathrm{X}_{\text {rain }}$

The mean enrichment factors (EF) $\mathrm{Cl}$ - and sea salt (SSF), crustal (CRF), and non-sea-saltnon-crustal (NSSCRF) fractions of dissolved ions in precipitation are shown in Table 5. An $(E F)_{\mathrm{Cl}}$ close to one means a marine origin, whereas, a large $(E F)_{\mathrm{Cl}}$ suggests that other sources are responsible. The results show clearly that $\mathrm{Na}^{+}$and $\mathrm{Mg}^{2+}$ have a $100 \%$ marine origin; even more since chloride ion was taken as the basis for excess calculations, obviously, sea salt also contributed with $100 \%$ for $\mathrm{Cl}^{-}$. Except, in Puerto 
Morelos and Tropical Pacific Ocean, the crust contribution was significant for $\mathrm{Ca}^{2+}$ and $\mathrm{K}^{+}$. In all cases, sulfate ion showed a marine fraction that depends on $\mathrm{Cl}^{-}$ion, and other fraction in excess with a non-marine source. Since the $\mathrm{NO}_{3}{ }^{-}$levels in seawater are very low, it was assumed that sea aerosol contribution to rainwater mineralization for this ion was zero, and, its origin in the case of Puerto Morelos at the end of the mid-summer drought, where high $\mathrm{NO}_{3}^{-}$levels were found, was an anthropogenic origin: The forest fires.

Table 5. Mean enrichment factors and sea salt, crustal and non-sea-salt-non-crustal fractions of ions in rainwater for all sampling sites in this research.

\begin{tabular}{|c|c|c|c|c|c|c|}
\hline Element & Acapulco & Cancún & Tapachula & $\begin{array}{l}\text { Puerto } \\
\text { Morelos* }\end{array}$ & $\begin{array}{l}\text { Tropical } \\
\text { Pacific } \\
\text { Ocean }\end{array}$ & $\begin{array}{l}\text { Puerto } \\
\text { Morelos }\end{array}$ \\
\hline \multicolumn{7}{|l|}{$\mathrm{Na}^{+}$} \\
\hline$(\mathrm{EF})_{\mathrm{Cl}}$ & 0.91 & 1.09 & 0.76 & 1.14 & 1.10 & 0.91 \\
\hline SSF(\%) & 100 & 100 & 100 & 100 & 100 & 100 \\
\hline CRF(\%) & 0 & 0 & 0 & 0 & 0 & 0 \\
\hline NSSCRF(\%) & 0 & 0 & 0 & 0 & 0 & 0 \\
\hline \multicolumn{7}{|l|}{$\mathrm{K}^{+}$} \\
\hline$(\mathrm{EF})_{\mathrm{Cl}-}$ & 1.37 & 3.81 & 9.2 & 1.32 & 0.64 & 0.40 \\
\hline SSF(\%) & 87 & 48 & 18 & 88 & 100 & 100 \\
\hline CRF(\%) & 13 & 52 & 82 & 12 & 0 & 0 \\
\hline NSSCRF(\%) & 0 & 0 & 0 & 0 & 0 & 0 \\
\hline \multicolumn{7}{|l|}{$\mathrm{Ca}^{2+}$} \\
\hline$(\mathrm{EF})_{\mathrm{Cl}-}$ & 2.66 & 14.63 & 10.40 & 2.65 & 1.05 & 0.90 \\
\hline SSF(\%) & 49 & 11 & 17 & 73 & 100 & 100 \\
\hline CRF(\%) & 51 & 89 & 83 & 27 & 0 & 0 \\
\hline NSSCRF(\%) & 0 & 0 & 0 & 0 & 0 & 0 \\
\hline \multicolumn{7}{|l|}{$\mathrm{Mg}^{2+}$} \\
\hline$(\mathrm{EF})_{\mathrm{Cl}-}$ & 0.97 & 0.87 & 1.96 & 1.14 & 0.71 & 0.92 \\
\hline SSF(\%) & 100 & 100 & 100 & 100 & 100 & 100 \\
\hline CRF(\%) & 0 & 0 & 0 & 0 & 0 & 0 \\
\hline NSSCRF(\%) & 0 & 0 & 0 & 0 & 0 & 0 \\
\hline \multicolumn{7}{|l|}{$\mathrm{SO}_{4}{ }^{2-}$} \\
\hline$(\mathrm{EF})_{\mathrm{Cl}-}$ & 2.2 & 2.43 & 14.7 & 2.26 & 1.61 & 1.74 \\
\hline SSF(\%) & 54 & 52 & 12 & 53 & 48 & 68 \\
\hline CRF(\%) & 0 & 0 & 0 & 0 & 0 & 0 \\
\hline NSSCRF(\%) & 46 & 48 & 88 & 47 & 52 & 32 \\
\hline \multicolumn{7}{|l|}{$\mathrm{Cl}^{-}$} \\
\hline$(E F)_{\mathrm{Cl}-}$ & 1.12 & 0.99 & 1.70 & 0.90 & 0.84 & 1.01 \\
\hline SSF(\%) & 100 & 100 & 100 & 100 & 100 & 100 \\
\hline CRF(\%) & 0 & 0 & 0 & 0 & 0 & 0 \\
\hline NSSCRF(\%) & 0 & 0 & 0 & 0 & 0 & 0 \\
\hline \multicolumn{7}{|l|}{$\mathrm{NO}_{3}^{-}-\mathrm{NH}_{4}^{+}$} \\
\hline$(\mathrm{EF})_{\mathrm{Cl}}$ & - & - & - & - & - & - \\
\hline SSF(\%) & 0 & 0 & 0 & 0 & 0 & 0 \\
\hline CRF(\%) & 0 & 0 & 0 & 0 & 0 & 0 \\
\hline NSSCRF $(\%)^{\circ}$ & 100 & 100 & 100 & 100 & 100 & 100 \\
\hline
\end{tabular}

* During mid-summer drought (2000). $\quad$ "In the plenitude of the wet season (2001).

Non-sea salt non-crustal fraction also can include fraction originating due biogenic activity in the sea surface (formation and oxidation of dimethyl sulfide). 


\section{CONCLUSION}

We can conclude that except for Puerto Morelos at the end of the mid-summer drought, all remaining sampling sites were clearly influenced by marine aerosol, showing ionic concentrations typical of sites with a minimal anthropogenic influence, and therefore, ionic concentrations measured can be considered as representative of background values for this region.

\section{ACKNOWLEDGMENTS}

This research was partially funded by the DGAPA-PAPIIT bureau of National University of Mexico, Project DGAPA - PAPIIT No. IN115198. The authors thank to MSc. Rocío García and BSc. María del Carmen Torres for their support in analytical work and their technical assistance., and M.C. Francisco Ruíz from the Academic Unit in Puerto Morelos, Sea and Limnology Sciences Institute, National University of Mexico, for his support. Also, the authors, acknowledge Dr. Fernando García for his support and providing partial funding for this research.

\section{REFERENCES}

Ahmed A.F.M., Singh R.P. and Elmubarak A.H. (1990), Chemistry of Atmospheric Precipitation at the Western Arabian Gulf Coast, Atmospheric Environment, 24 A, 2927-2934.

Báez A.P. and Belmont R. D. (1987), Comparative Study of the Chemical Composition of Rain of Three Different Zones in Mexico, Contaminación Ambiental, 3, 25-36.

Báez A.P., Belmont R.D. and Padilla H.G. (1993), Variation of Chemical Composition of Wet Precipitation, Using a Sequential Sampling: Urban-Rural Areas Comparison, Atmósfera, 6, 163-174.

Báez A.P., Belmont R.D. and Padilla H.G. (1997 a), Chemical Composition of Precipitation at Two Sampling Sites in Mexico: A 7-year Study, Atmospheric Environment, 31, 915-925.

Báez A.P., Padilla H.G., Cervantes J., Pereyra D. and Belmont R.D. (1997 b), Rainwater Chemistry at the Eastern Flanks of the Sierra Madre Oriental, Veracruz, Mexico, Journal of Geophysical Research, 102, 23329-23336.

Bravo H.A., Saavedra M.I., Sánchez P.A., Torres R.J. and Granada L.M. (2000), Chemical Composition of Precipitation in a Mexican Maya Region, Atmospheric Environment, 34 B, 1197-1204.

Casimiro A.P., Salgueiro M.L. and Nunez V.T. (1991), Seasonal and Air-mass Trajectory Effects on Rainwater Quality at the Southwestern European Border, Atmospheric Environment, 25 A, 2259-2266.

Cerón R.M.B., Padilla H.G., Belmont R.D., Torres M.C.B., García R.M. and Báez A.P. (2002), Rainwater Chemical Composition at the End of the Mid-summer Drought in the Caribbean Shore of the Yucatan Peninsula, Atmospheric Environment, 36, 2367-2374.

Cerón R.M.B. (2002) Composición química de la precipitación pluvial en zonas costeras. PhD.Thesis. National University of Mexico. Center of Atmospheric Sciences.

Clark K.L., Nadkarni N.M., Schaefer D. and Gholz H.L. (1998), Cloud Water and Precipitation Chemistry in a Tropical Montane Forest, Monteverde, Costa Rica, Atmospheric Environment, 32, 1595-1603.

Culkin F. and Cox R.A. (1966), Sodium, Potassium, Magnesium, Calcium and Strontium in Sea Water, Deep Sea Research, 13, 789-804.

Duce R.A. and Hoffman E.J. (1976), Chemical Fractionation at the Air/Sea Interface, Ann. Rev. Earth PlanetSci, 4, 187-228.

Eklund T.J., McDowell W.H. and Pringle C.M. (1997), Seasonal Variation of Tropical Precipitation Chemistry: La Selva, Costa Rica, Atmospheric Environment, 31, 3903-3910.

Galloway J.N. and Likens G.E. (1978), The Collection of Precipitation for Chemical Analysis, Tellus, 30, 71-82.

Galloway J.N., Likens G.E., Keene W.C. and Miller J.M. (1982), The Composition of Precipitation in Remote Areas of the World, Journal of Geophysical Research, 87, 8771-8776.

Galloway J.N., Knap A.H. and Church T.M. (1983), The Composition of Western Atlantic Precipitation Using Shipboard Collectors, Journal of Geophysical Research, 88, 1085910864.

Galloway J.N., Keene W.C., Artz R.S., Miller J.M., Church T.M. and Knap A.H. (1989), Process Controlling the Concentrations of $\mathrm{SO}_{4}^{2-}, \mathrm{NO}_{3}^{-}, \mathrm{NH}_{4}^{+}, \mathrm{H}^{+}, \mathrm{HCOO}$ and $\mathrm{CH}_{3} \mathrm{COO}_{\mathrm{T}}$ in Precipitation on Bermuda, Tellus, 41 B, 427-443. 
Hendry C.D., Berish C.W. and Edgerton E.S. (1984), Precipitation Chemistry at Turrialba, Costa Rica, Water Resources Research, 20, 1677-1684.

Lim B., Jickells D.T. and Davies T.D. (1991), Sequential Sampling of Particles, Major Ions and Total Trace Metals in Wet Deposition, Atmospheric Environment, 25 A, 745-762.

McDowell W.H., Ginés S.C., Asbury C.E. and Ramos P.C. (1990), Influence of Sea Salt Aerosols and Long Range Transport on Precipitation Chemistry at El Verde, Puerto Rico, Atmospheric Environment, 24 A, 2813-2821.

Morris A.W. and Riley J.P. (1966), The Bromide/Chlorinity and Sulfate/Chlorinity Ratio in Sea Water, Deep Sea Research, 13, 699-705.

Peden E.M., Bachman S.R., Brennan C.J., Demir B., James K.D., Kaiser B.W., Lockard J.M., Rothert J.E., Sauer J., Skowron L.M. and Slater M.J. (1986), Development of Standard Methods for the Collection and Analysis of Precipitation, Contract CR810780-01, Analytical Chemistry Unit I11, State Water Survey, Champaign, IL.

Raynor G.S. and Hayes J.V. (1982), Variation in Chemical Wet Deposition with Meteorological Conditions, Atmospheric Environment, 16, 1647-1656.

Savoie L.D., Prospero J.M. and Nees R.T. (1987), Washout Ratios of Nitrate, Non-Sea-Salt Sulfate and Sea-Salt on Virginia Key, Florida and on American Samoa, Atmospheric Environment, 21, 103-112.

Saylor R.D., Butt K.M. and Peters L.K. (1992), Chemical Characterization of Precipitation from a Monitoring Network in the Lower Ohio River Valley, Atmospheric Environment, 26 A, 11471156.

Seymour D.M. and Stout T. (1983), Observations on the Chemical Composition of Rain Using Short Sampling Times During a Single Event, Atmospheric Environment, 17, 1483-1487.

Singh B., Norbert M. and Zwack P. (1987), Rainfall Acidity as Related to Meteorological Parameters in Northern Quebec, Atmospheric Environment, 21, 825-842.

Vong R.J. (1990), Mid-latitude Northern Hemisphere Background Sulfate Concentration in Rainwater, Atmospheric Environment, 24 A, 1007-1018. 